\title{
LOAD DISPATCH AND REPLACING DIESEL BY GAS POWER PLANT TO REDUCE PRODUCTION COST OF POWER GENERATION IN BALI ISLAND
}

\author{
IAD Giriantari, WG.Ariastina \\ Department of Electrical Engineering \\ Udayana University, Bali, Indonesia \\ Telp/Fax: +62 361703315 \\ e-mail: dayu.giriantari@unud.ac.id, w.ariastina@unud.ac.id
}

\begin{abstract}
Bali Island is powered from three power plants and from Jawa Island through marine cables. The power plant in Bali use diesel fuel which result in high production cost. Meanwhile the production cost at Jawa Island is lower because most of power plants use coal fuel. Supply from Jawa Island is limited 200MW but now days use as peaker and supply from diesel power plants in Bali which are mostly old machine run in full power. This condition has caused high production cost. Therefore we proposed to change the load dispatch and replace the old diesel by gas power plant. The simulation has shown a much lower production cost. The lowest cost is found for the transfer Jawa-Bali in optimum capacity.
\end{abstract}

\section{Introduction}

Bali island power supply is part of Jawa-Bali power system which has capacity in total of $28.070 \mathrm{MW}$ and availability of 26.215 MW (August 2012). Bali is connected trough marine cables to Jawa Island where most of power plant installed with capacity of $200 \mathrm{MW}$. There are only 3 small power plants in Bali: Gilimanuk with capacity of 130 MW, Pemaron with capacity installed of $136 \mathrm{MW}$, and Pesanggaran with capacity installed of $230 \mathrm{MW}$.

Power plant of Pesanggaran is the oldest power plant in Bali which consists of 4 Gas engines and 11 Diesel engines. However, all engines were run by using High Speed Diesel. Gilimanuk power plant consist of 1 unit gas engine, meanwhile Pemaron power plant consist of 2 units gas engine and 1 unit $\mathrm{BOO}$ diesel engine.

The average of energy production cost of Gas engine is IDR $2079.39 / \mathrm{kWh}$ (USD $0.22 / \mathrm{kWh}$ ) and diesel engine is IDR $3750.07 / \mathrm{kWh}$ (USD $0.4 / \mathrm{kWh}$ ). Those value determine by using diesel cost is IDR 9,806.85/liter and LNG cost include transport and regasification is IDR 171,000/MMBTU. Moreover, the energy cost from JawaBali transfer is IDR $860.24 / \mathrm{kWh}$. We have done simulation for the production cost of energy system Bali In order to get the cheapest energy cost in Bali.

Simulation for one day supply of existing condition where all unit are run by High Speed Diesel (HSD) fuel and transfer Jawa-Bali is not optimum. Simulation is also done for the same day and the same load dispacth of system, but the gas engines are run by LNG and diesel engine run by diesel. The third simulation is done by taking transfer Jawa-Bali on optimum and all generation unit in Bali are run by HSD.

\section{Power System of Bali}

The power system of Bali is connected to Jawa system by marine cable. Total capacity installed of Bali system is $623 \mathrm{MW}$. The largest load is in the southern part of island where most of the tourist attraction is placed. Pesanggaran Power Plant is also on the southern part of island near the harbor of Benoa.

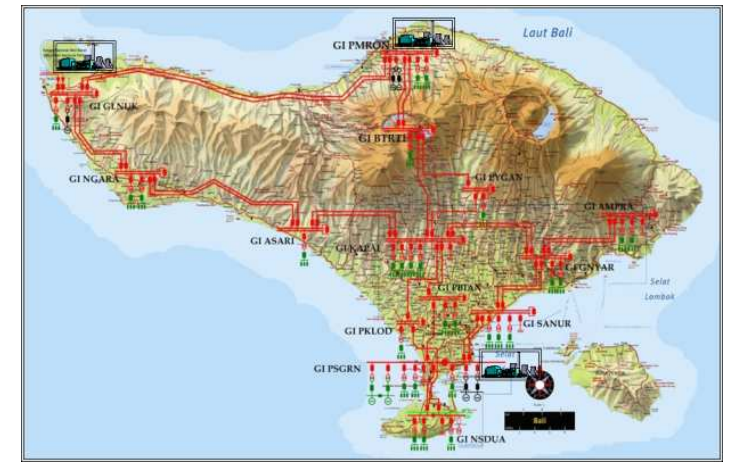

Figure 1. Power generation and transmission of Bali

The diesel engine at Pesanggaran power plant are old and been in service since 1950's. Most of them still performing good, the plan to replace them with gas power plant due to the increasing load. The decision to use LNG is based on the geographic condition of Bali and based on the fact that Indonesia has very big resource of LNG. There are three placed where the LNG is produced: Arun 
Gas Field with its capcity of 12.85 Million Metric Ton Per Annum/MMTPA, Bontang Gas Field with capacity of 21.64 MMTPA, and Tangguh Gas Field with capacity 7.6 MMTPA. There will be built three other gas fields with much larger capacity.

Bali Island does not have gas resource and gas utility system. Bali does not have oil resource either. Diesel oil and Gas are supplied from other island on the ground transportation. Therefore, gas supply for Pesanggaran Power Plant will utilize the Floating Storage and Regasification Unit (FSRU) therefore there will not need storage system on the ground.

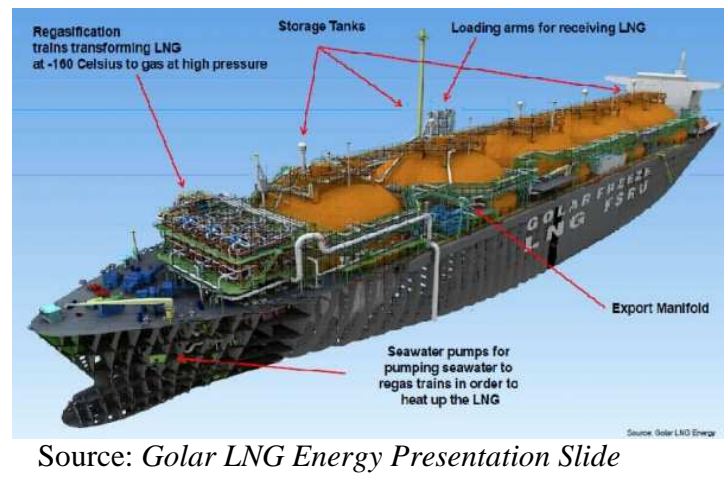

Figure 2. Floating Storage and Regasification Unit (FSRU)

The load profile of Bali system is typical as a residential profile as seen on the figure 3 which need a proper load dispatch for optimum cost.

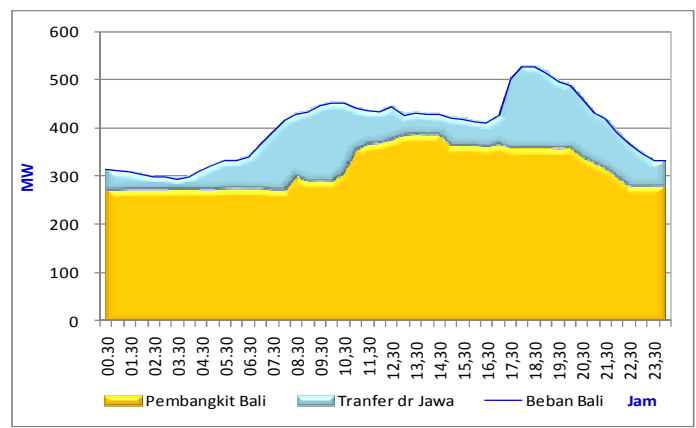

Figure 3. Load profile and existing load dispatch of Bali

\section{Production Cost Analysis}

Production cost analysis of power system Bali is done by using one day load condition which is the system load on 28th May 2012. The 11 diesel engines at Pesanggaran power plant is divide into 1 unit BOO diesel, and 1 unit BOT diesel, and 1 unit composite diesel. It makes Pesanggaran power plant consisto g 4 gas engines, 1 diesel engine, 1 BOO diesel engine, and 1 BOT diesel engine. Gilimanuk power plant has 1 unit gas engine, Pemaron power plant has 2 gas engine and 1 composite unit diesel engine..

\section{Scenario 1: Existing condition}

There are 11 units engines installed in 3 locations of power plants in Bali. There is 1 gas engine in Gilimanuk power plant, there are 2 gas engines and 1 diesel engine (BOO) in Pemaron power plant, 4 gas enginest and 3 diesel engines ( 2 are BOO and 1 BOT) in Pesanggaran power plant. All units gas and diesel are fueled by High Speed Diesel (HSD).

This study uses the load condition on the 28th May 2012 as an example. The graph of the load dispacth on that day is shown in figure 4.

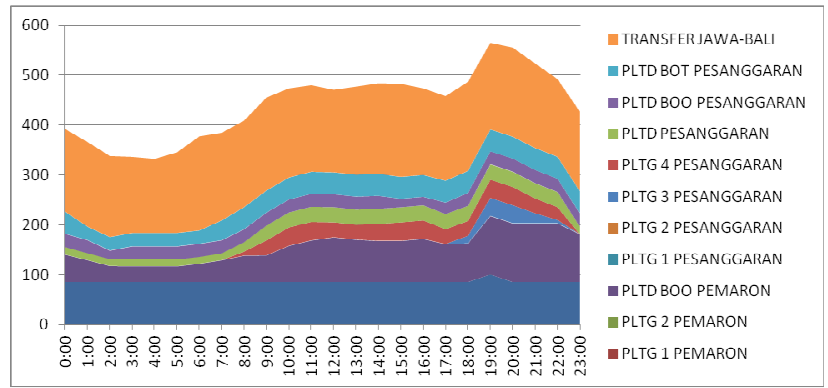

Figure 4. Load dispatch on the 28 May 2012

All gas engine at Pemaron and 2 unit at Pesanggaran did not supply any power. Unit 4 of gas engine at Pesanggaran started supply when the load increase at 9 am, and unit 3 started supply during peak load. The gas engine at Gilimanuk, a diesel engine at Pemaron, and 3 diesel engines at Pesanggaran supply all the time in addition to power transfer from Jawa island.

The production cost equation of each unit if they are fueled by HSD is determined base on load test data shows in Table 1 below.

Table 1. Production cost equation all unit are fueled by HSD

\begin{tabular}{|c|l|l|}
\hline NO & \multicolumn{1}{|c|}{ UNIT NAME } & \multicolumn{1}{c|}{ EQUATION (Fx) } \\
\hline 1 & PLTG GILIMANUK & $8405.87 x^{2}+252176.14 x+224156571.43$ \\
\hline 2 & PLTG 1 PEMARON & $26247.49 x^{2}+752447.77 x+76392592.88$ \\
\hline 3 & PLTG 2 PEMARON & $23374.41 x^{2}+952207.23 x+77675709.15$ \\
\hline 4 & BOO PEMARON & $441.02 \times 2+2446320.41 x+2717313.68$ \\
\hline 5 & PLTG 1 PESANGGARAN & $38187.40 x^{2}+230834.55 x+58987271.50$ \\
\hline 6 & PLTG 2 PESANGGARAN & $80318.17 x^{2}+1776080.73 x+20839110.10$ \\
\hline 7 & PLTG 3 PESANGGARAN & $6216.35 x^{2}+1941063.99 x+44697379.38$ \\
\hline 8 & PLTG 4 PESANGGARAN & $34345.75 x^{2}+1053922.14 x+52944756.23$ \\
\hline 9 & PLTD PESANGGARAN & $2966.72 x^{2}+2252824.53 x+10532980.02$ \\
\hline 10 & BOO PESANGGARAN & $1748.83 \times 2+2197388.75 x+3487218.68$ \\
\hline 11 & BOT PESANGGARAN & $3062.38 x 2+2147655.80 x+3912632.63$ \\
\hline 12 & TRANSFER JAWA-BALI & $387.11 x^{2}+782818.40 x$ \\
\hline
\end{tabular}

The total production cost of the Bali power system on the 28th May 2012 existing state is found of IDR $29,697,351,338$ equivalent to USD $3,045,882$

Scenario 2: Dispatch as existing, the gas power plant fueled by LNG and diesel fueled by HSD

Simulation has run by using same load dispatch as the existing, then the gas engines are fueled by Liquid Natural Gas and diesels are fueled by HSD. The production cost equations of each unit are derived and shows in Table 2. 
Table 2. Production cost equation scenario 1

\begin{tabular}{|c|l|l|}
\hline NO & \multicolumn{1}{|c|}{ UNIT NAME } & \multicolumn{1}{c|}{ EQUATION (Fx) } \\
\hline 1 & PLTG GILIMANUK & $8405.87 x^{2}+252176.14 x+224156571.43$ \\
\hline 2 & PLTG 1 PEMARON & $26247.49 x^{2}+752447.77 x+76392592.88$ \\
\hline 3 & PLTG 2 PEMARON & $23374.41 x^{2}+952207.23 x+77675709.15$ \\
\hline 4 & BOO PEMARON & $441.02 \times 2+2446320.41 x+2717313.68$ \\
\hline 5 & PLTG 1 PESANGGARAN & $11177.60 \times 2+67566.18 x+17265806.56$ \\
\hline 6 & PLTG 2 PESANGGARAN & $21931.63 \times 2+484975.50 x+5690314.42$ \\
\hline 7 & PLTG 3 PESANGGARAN & $2251.49 x 2+703031.15 x+16188879.03$ \\
\hline 8 & PLTG 4 PESANGGARAN & $11090.36 x 2+340315.20 x+17096049.67$ \\
\hline 9 & PLTD PESANGGARAN & $2966.72 x^{2}+2252824.53 x+10532980.02$ \\
\hline 10 & BOO PESANGGARAN & $1748.83 \times 2+2197388.75 x+3487218.68$ \\
\hline 11 & BOT PESANGGARAN & $3062.38 \times 2+2147655.80 x+3912632.63$ \\
\hline 12 & TRANSFER JAWA-BALI & $387.11 x^{2}+782818.40 x$ \\
\hline
\end{tabular}

The ttotal production cost of Bali power system on the 28th May 2012 with this scenario is found of IDR $25,945,563,760$ or USD 2,661,083 (1USD=IDR 9750). The one day production cost of this scenario is less than existing state by IDR $3,751,787,578$ or USD 384,798 .

\section{Scenario 3: Transfer Jawa-Bali optimum and all power plants gas and diesel are fueled by HSD}

A simulation also has been done if the transfer JawaBali on optimum capacity, the gas and diesel power plant fueled by HSD. Gas engines at Pemaron are turn off during 00.00-08.00, and diesel engines at Pesanggaran are turn off during 01.00-05.00. The production cost equation of each unit is shown in Table 3.

Table 3. Production cost equation of scenario 2

\begin{tabular}{|c|l|l|}
\hline NO & \multicolumn{1}{|c|}{ UNIT NAME } & \multicolumn{1}{c|}{ EQUATION (Fx) } \\
\hline 1 & PLTG GILIMANUK & $8405.87 x^{2}+252176.14 x+224156571.43$ \\
\hline 2 & PLTG 1 PEMARON & $26247.49 x^{2}+752447.77 x+76392592.88$ \\
\hline 3 & PLTG 2 PEMARON & $23374.41 x^{2}+952207.23 x+77675709.15$ \\
\hline 4 & BOO PEMARON & $441.02 x 2+2446320.41 x+2717313.68$ \\
\hline 5 & PLTG 1 PESANGGARAN & $38187.40 x^{2}+230834.55 x+58987271.50$ \\
\hline 6 & PLTG 2 PESANGGARAN & $80318.17 x^{2}+1776080.73 x+20839110.10$ \\
\hline 7 & PLTG 3 PESANGGARAN & $6216.35 x^{2}+1941063.99 x+44697379.38$ \\
\hline 8 & PLTG 4 PESANGGARAN & $34345.75 x^{2}+1053922.14 x+52944756.23$ \\
\hline 9 & PLTD PESANGGARAN & $2966.72 x^{2}+2252824.53 x+10532980.02$ \\
\hline 10 & BOO PESANGGARAN & $1748.83 \times 2+2197388.75 x+3487218.68$ \\
\hline 11 & BOT PESANGGARAN & $3062.38 x 2+2147655.80 x+3912632.63$ \\
\hline 12 & TRANSFER JAWA-BALI & $387.11 x^{2}+782818.40 x$ \\
\hline
\end{tabular}

The total production cost for this scenario is IDR $25,401,953,073$ or USD 2,605,328. It is IDR $4,295,398,264$ or USD 440,553 cheaper than the existing dispatch.

By doing simulation on 3 different condition system load, it is found that the lowest energy cost is the condition of transfer Jawa-Bali on optimum capacity and all engine unit in Bali run by HSD fuel. The production cost also found decreasing when the gas engine run by LNG and diesel run by diesel oil. The graph of those 3 scenarios production cost shows in figure 5 .

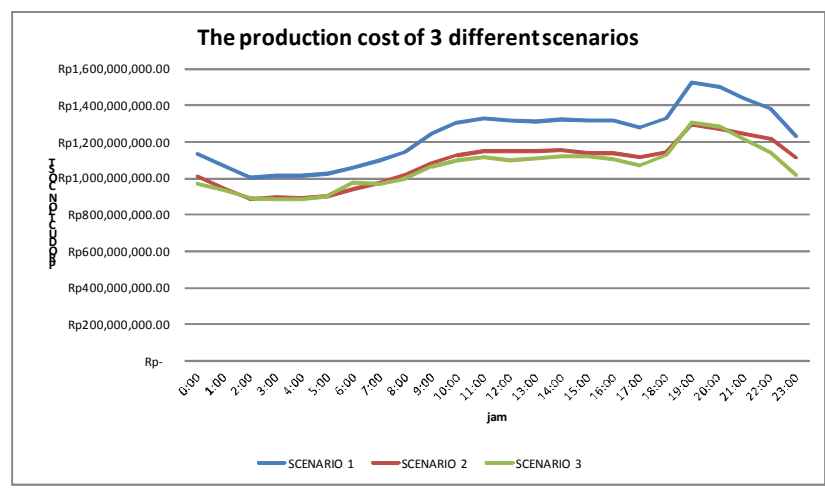

Figure 5. The graph of production cost of 3 different scenarios for the 28th May 2012 system load

The production cost which effect the energy cost in Bali island can be reduced about IDR4,295,398,264 or USD 440,553 a day only by changing the system load dispatch. The energy cost in Bali can be even more lower by applying dispatch on optimum capacity transfer JawaBali and change the old diesel engine inti new gas engines, however it need high investment.

\section{Conclusion}

The production cost of power generation in Bali island can be reduced signifantly by changing the system load dispatch, and will be even more reduced by replacing the old diesel engine by gas engines.

\section{Reference:}

[1] PT. Indonesia Power Subregion Bali " Annual Report of Power Generation of Bali", 2011

[2] Kumar,A." Distributed generation location based on fuel cost minimization in deregulated electricity markets" India C onference, 2008. INDIC ON 2008. Annual IEEE

[3] Utama,N.A."National energy policy; a least cost option" Clean Energy and Technology (CET), 2011 IEEE First Conference on

[4] Watada, J. Service cost optimization in supply balance of sustainable power generationTechnology Management in the Energy Smart World (PICMET), 2011 Proceedings of PIC MET '11

[5] PT. PLN (Persero)"Master Plan of System Operation Java-Bali 2011-2016" 